\title{
ALMOST EVERYTHING ABOUT TOEFL PBT
}

Submitted as One of Language Testing Assignments Taught by Budianto Hamuddin M. Pd.

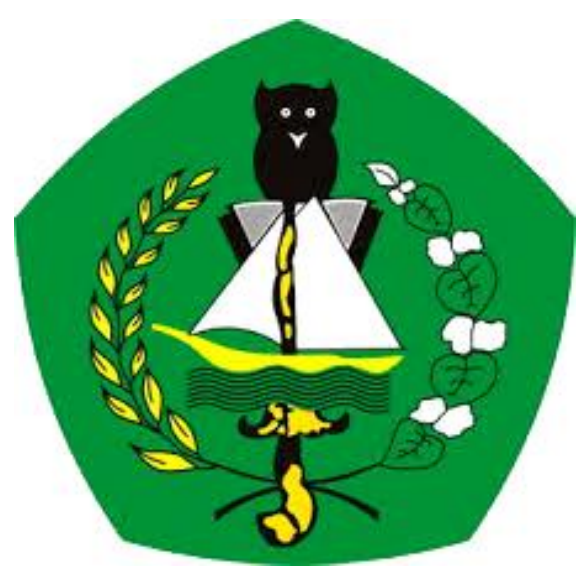

The Author :

Nurul Fathia Salma

\section{ENGLISH EDUCATION DEPARTMENT \\ FACULTY OF TEACHERS TRAINING AND EDUCATION \\ UNIVERSITY OF LANCANG KUNING}

MAY 2018/2019 


\begin{abstract}
This article briefly reviews the development of TOEFL wich is widely acknowledged. one of the formats of TOEFL discussed is TOEFL PBT. All ever you wanted to know about TOEFL PBT such as the specific aspects on review are the hostory, characteristics, structures and the strategies of TOEFL PBT as a testing instrument. Besides, this paper also discussed the total of questions applied in every section of the test.
\end{abstract}

Keyword : TOEFL, TOEFL PBT, ASPECT OF TOEFL PBT. 


\section{PREFACE}

First of all, I would like to say deeply and grateflul thank you to Allah SWT. that has given health, thanks to Allah SWT. for helping and give the writer chance to finish this paper entitled "Almost Everrything about TOEFL PBT". This paper is made to complate one of Language Testing assignments.

I would like to say thank you to Mr. Budianto Hamuddin, M.Pd. as the lecturer that always teaches us and give much knowledge about Language Testing.

I relized this paper is not perfect yet. But I hope it can be useful for us. Critics and suggestion are needed here to make this paper better. Hopefully, we as a student in English Department can work more professional.

Pekanbaru, May $20^{\text {th }}, 2018$

The Author

Nurul Fathia Salma 


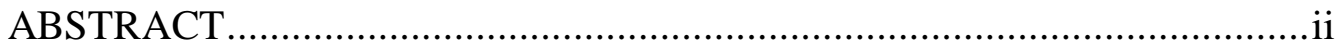

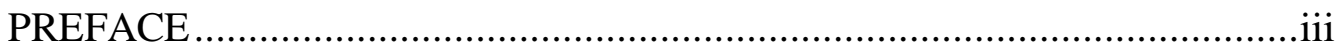

TABLE OF CONTENTS ...........................................................................

CHAPTER I INTRODUCTION TO THE COURSE ................................... 1

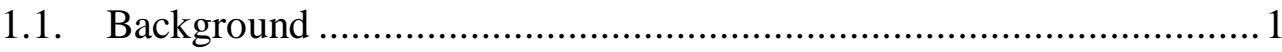

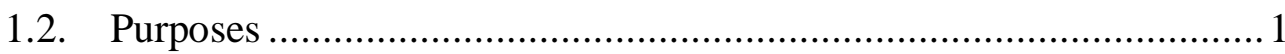

CHAPTER II CONTENT ....................................................................... 2

2.1 What is TOEFL PBT (Paper-Base Test ? .................................... 2

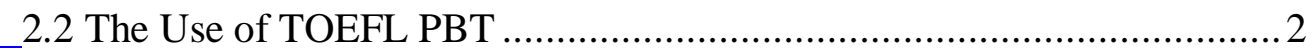

2.3 Participant of TOEFL PBT Test ...................................................... 3

2.4 Receiver of TOEFL PBT Test Score .................................................... 3

2.5 The Aspect of TOEFL Test PBT (Paper Based Test)........................... 3

2.6 Structure of TOEFL Test PBT (Paper Based Test) .......................... 4

2.6.1 Listening Comprehension....................................................... 4

2.6.2 Structure and Written Expression ........................................ 4

2.6.3 Reading Comprehension ................................................... 4

2.6.4 Test of Written English .........................................................

2.7 The Difficulties in TOEFL Test ......................................................... 5

2.8 Some Strategies in Doing Toefl Test ................................................. 6

2.8.1 The Strategies in Listening Section ......................................... 7

2.8.2 The Strategies in Reading Comprehension Section........................ 8

2.8.3 The Strategies in Structure \& Written Expression Section .............. 8 
2.8.4 The Strategies in Test of Written English Section.

2.9 What is the required TOEFL score? .......................................... 10

2.10 Classification of TOEFL Test SCORE ............................................ 10

2.11 Time of the TOEFL Test Exam ...................................................... 10

2.12 Cost of TOEFL PBT Test .......................................................... 11

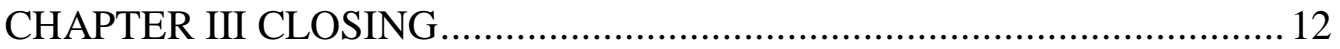

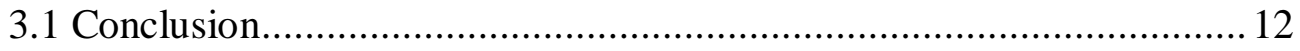

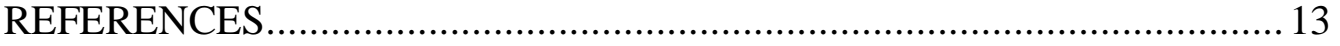




\section{CHAPTER I}

\section{INTRODUCTION TO THE COURSE}

\subsection{Background}

TOEFL is the abbreviation of Test of English as a Foreign Language. it is a test to gage the English language ability of nonnative speakers who want to register in English-speaking universities. Many English- Speaking academic accept this test. no exception the professional institution. This test is one of the two major tests of English-language which is used in the world and the second is IELTS.

Toefl stands under the organization which administers and designs the tests, ie Educational Testing Service (ETS) since 1965. The TOEFL test was first sparked in 1962 by an American council as a foreign language on the testing of English. Originally, TOEFL was developed under the direction of Stanford University at the Center for Applied Linguistics by a linguistics professor Dr. Charles A. Ferguson. The TOEFL test was first implemented in 1964 by the Modern Language Association financed by grants from the Ford Foundation and Danforth Foundation.

TOEFL Test always doing the development. Thus far, TOEFL has four successive major formats: pBT, cBT, iBT and iTP. Therefore, the author will discuss everything about $\mathrm{pBT}$ which is the first format of the TOEFL Test.

\subsection{Purposes}

The author writes this paper which has the purposes, inter alia :

1. To know the history of TOEFL in the overall.

2. To know what is the first format of TOEFL Test and the characteristic.

3. To know how to through the tes successfully in avery passage of the test. 


\section{CHAPTER II \\ CONTENT}

\subsection{What is TOEFL PBT (Paper-Base Test ?}

TOEFL PBT (Paper- Based Test is one of the types of the TOEFL Test which is familiar be run in every institute, courses, specialized language institutes, etc. It is the first TOEFL issued by ETS (English Testing Service).

This test use arrangged in a paper-and-pencil format, to measure the test takers' ability to use and understand English in a classroom, at the college or university level. It conscientiously measured how well the takers could listen, write and read in English while performing academic tasks. It included the TWE a 30-minute writing test.

It belonging the TWE (Test Written English) test, a 30-minute writing test. Test takers should write a short essay on one topic from their TWE test books to show their ability to:

- Produce and organize the ideas

- Use standard written english formats

- Support ideas in writing in concert with examples or substantiation

In the other words, the material tested are Listening, Structure, Reading and sometimes the test used TWE.

Started since July 2017, the TOEFL PBT test was discontinued and replaced by the revised TOEFL Paper-delivered Test. The new paper test is more closely to the TOEFL iBT test. The score range of PBT Test are 217-677. The duration of the test $2-2,5$ hours. The validity of TOEFL Score is for 2 years begin after your test date.

\subsection{The Use of TOEFL PBT}

By taking the TOEFL PBT test, the test takers received the following benefits:

1. Can qualify for school or college graduation.

2. Can apply for a scholarship / exchange student program.

3. Can assess the progress of learning achieved. 
4. Can apply for jobs offered by companies or large agencies.

5. TOEFL provides practical and valuable knowledge and skills.

\subsection{Participant of TOEFL PBT Test}

The usual test participants are:

- Those who plan to study abroad especially the process of teaching and learning using English.

- People who will be employees of a government agency (CPNS / PNS).

- Scholarship recipients.

- The students who will undergo the graduation process (candidate degree).

\subsection{Receiver of TOEFL PBT Test Score}

More than 8,000 universities and educational institutions in more than 130 countries receive TOEFL test results. In addition, there are some ordinary parties that require TOEFL score to meet certain requirements, eg to become employees or to take a higher level of education. These parties, among others:

- Department of Immigration

- Institute of Health and Licensing

- Individual

- Companies

\subsection{The Aspect of TOEFL Test PBT (Paper Based Test)}

\section{Tabel 2.1}

The Aspect of TOEFL Test PBT

\begin{tabular}{|l|c|r|}
\hline \multicolumn{1}{|c|}{ Sub Test } & Number of Questions & Duration \\
\hline Listening Comprehension & 50 & 40 minutes \\
\hline Structure \& Written Expression & 40 & 25 minutes \\
\hline Reading Comprehension & 50 & 55 minutes \\
\hline Test of Written English & 1 Topic & 30 minutes \\
\hline \multicolumn{2}{|c|}{ Total Duration } & $\mathbf{2 , 5}$ hours \\
\hline
\end{tabular}




\subsection{Structure of TOEFL Test PBT (Paper Based Test)}

TOEFL consists of three parts (sections) with 140 questions. This TOEFL test always starts with Listening Comprehension which consists of Part (parts) A, B and C, then forwarded with Structure and Written Expression which consists of Part A and B, and the last is Reading Comprehension.

\subsubsection{Listening Comprehension}

The Listening section consists of 3 parts. The first part contains 30 questions about short conversations. The second part contains 8 questions about longer conversations and the last part asks 12 questions about talks or lectures. This section tests your ability to listen to short conversation or short speeches in English through tape or other audio media provided by the TOEFL test committee.

- The number of questions on this chart is: 50 questions

- Duration: 40 minutes.

\subsubsection{Structure and Written Expression}

The Structure and Written Expression has 40 exercises in overall included 15 exercises of completing sentences correctly. This section tests your ability to understand the grammars and phrases that are prevalent in the English language. Besides, 25 next exercises of identifying errors. This section demands your ability in understanding and knowing the location of the error of the phrase or grammar.

- Number of questions: 40 questions

- Duration: 25 minutes.

\subsubsection{Reading Comprehension}

This section test your ability to understand various types of scientific reading related to topics, main ideas, reading content, meaning of words or groups of words, as well as detailed information relating to the reading. Because the level 
of vocabulary and text difficulty levels used in the reading are quite high, you should use the right strategy in working on this section.

- Number of questions: 50 questions

- Duration: 55 minutes.

\subsubsection{Test of Written English}

This section tests your ability to write an essay. You will be given a specific topic and then you are asked to pour in short essay writing. This is one essay question with 250-300 words in average. Test of Written English scores are given separately from the TOEFL score overall. The scoring scale ranges from 1-6. If Test of Written English (TWE) includes the part tested in a TOEFL test, it is usually executed before the Listening Comprehension exam.

- Number of questions: 1 topic

- Duration: 30 minutes.

\subsection{The Difficulties in TOEFL Test}

The TOEFL test is one of the most important tests to master. not a few people who failed in implementing the TOEFL test. So, we should know, the usual difficulty in carrying out the TOEFL test and after that we have to know how to overcome the difficulty to minimize failure.

1. The cause of the TOEFL test is difficult because of the lack of preparation such as the information that related with learning TOEFL.

2. Ability to Hear Conversation. In the TOEFL test the entire conversation and lecture is done by the native speaker then the intonation, pronunciation and speaking speed will often make it difficult for you, especially if you are not used to listen to native speakers.

3. Pronunciation problem. English has a different way of pronunciation with Indonesian so it will require extra effort to learn. This will be one of the obstacles especially when facing SPEAKING SESSION. You are required to pronounce every word correctly. 
4. Less master of English grammar. Grammar becomes very important, be it in terms of verbal or non-verbal exams because grammatical errors can change the meaning, for example is the formation of active and passive sentences.

5. The problem of vocabulary wealth. It is very natural for someone to have difficulty in saying and speaking English if you do not have enough vocabulary. In addition, in English, there are words that have multiple meanings and words that make up the idiom

6. Your psychological aspect. Sometimes when it comes to tests there is a feeling of nervousness and fear of disturbing your concentration, causing you to be unable to think clearly and respond appropriately

7. Time allocation problem. In the TOEFL test there are many questions that must be solved in a fast tempo, therefore you are required to be able to effectively and efficiently make your time.

8. Availability of facilities, such as paper, computers, networks, earphones and microphones. These facilities can be described as worksheets, so if there is damage to the facility, of course it will greatly affect the answer you provide.

9. Lack of ability to express opinions, both verbally and in writing. When you can not express the idea coherently and clearly, this will surely greatly affect your judgment on a written test.

10. Lack of general insight. This is the ultimate cause of the difficulty of doing TOEFL exam questions. When performing the TOEFL test this general insight will be needed, especially when you need to create an ESSAY based on a given theme.

\subsection{Some Strategies in Doing Toefl Test}

Strategy is needed in the face of the TOEFL test to help us overcome the failure when completing the TOEFL test and pass the test successfully, the strategies are the following : 


\subsubsection{The Strategies in Listening Section}

There are three parts of Listening Section. First, short dialogue. Second, long conversation. Third, talks. To answer all of the question easily, there are some general strategies that you should do in this section, ie :

1. Be familiar with the direction.

2. Listening carefully to the passage.

3. Know the easier and the more difficult questions.

4. Be familiar with the pacing of the test.

5. Never leave any answer blank.

6. Use any remaining time to look ahead at the questions that follow.

7. Focus on the Last Line:

- The last line of dialogue probably contains the answer to the question.

- Listen to the first line of the dialogue. If you understand it, that's good. If you don't understand it, don't worry because it probably does not contain the answer.

- Be ready to focus on the last line of the the dialogue because it probably contains the answer. Repeat the last line in your mind as you read through the answer in the text.

8. Choose answer with synonyms

- As you listen to the last line of the dialogue, focus on key words in that line.

- If you see any synonyms for key words in a particular answer, then you have probably found the correct answer

9. Avoid similar sounds

- Identify key words in the last line of the dialogue.

- Identify words in the answers that contain similar sounds, and do not choose these answer.

10. Draw conclusions about: Who, what, where.

11. Listen for: Who \& What In Passive sentence in the dialogue. 
- If the dialogue contains a passive statement, the answer to the question is often an active statement.

- If the dialogue contains an active statement, the answer to the question is often a passive statement.

\subsubsection{The Strategies in Reading Comprehension Section}

1. Be familiar with the directions.

2. Do not spend too much time reading the passages.

3. Do not worry if a reading passage is on a topic you are unfamiliar with.

4. Do not spend too much time on a question you are unsure of.

5. Guess to complete the section before time is up.

6. Answer Main Idea Question Correctly

7. Recognize the Organization of Ideas

8. Answer Stated Detail Questions Correctly

9. Find "Unstated" Details

10. Determine Meanings from Word Parts

11. Use Context To Determine Meanings of Difficult Words.

\subsubsection{The Strategies in Structure \& Written Expression Section}

1. Be familiar with the directions.

2. Begin with questions I through I5.

3. Continue with questions I6 through 40 .

4. If you have time, return to questions II through I5.

5. Guess to complete the section before time is up.

6. Do not leave answer sheets blank.

There are some specific strategies in doing Structure \& Written Ekspression, ie :

1. Be Sure the Sentence Has a Subject and a Verb

- A sentence in English must have at least one subject and one verb.

2. Be Careful of Objects of Prepositions 
- A preposition is followed by a noun, pronoun, gerund or noun clause that is called an object of the preposition. If a word is an object of a preposition, it is not the subject.

3. Be Careful of Appositives

- An appositives is a noun that comes before or after another noun is generally set off from the noun with commas. If a word is an appositives, it is not the subject. The following appositive structures are both possible in English:

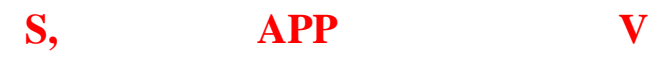

Tom, a really good mechanic is fixing the car.

4. Be Careful of Present Participles

- A present participle is the -ing form of the verb. The present partciple can be (I) part of the verb (2) an adjective. It is part of the verb when it is accompanied by some form of the verb be. It is an adjective when it is not accompanied by some form of the verb be.

1. The boy is standing in the corner.

2. The boy standing in the corner was naughty.

5. Use Coordinate Connectors Correctly

6. Use Adverb Time and Cause Connectors Correctly

7. Use Other Adverb Connectors Correctly

8. Use Noun Clause Connectors Correctly

9. Use Noun Clause Connector/Subjects Correctly

10. Invert the Subject and Verb with Question Words

\subsubsection{The Strategies in Test of Written English Section.}

1. Read the question carefully, the question exactly as it is asked.

2. Organize your response very clearly.

3. Whenever you make any general statement, be sure to support that statement.

4. Stick to vocabulary and sentence structures that you know.

5. Finish writing your essay a few minutes early so that you have time to proof and read what you wrote. 
6. Determine the Topic

7. Write the Introductory Paragraph

8. Write Unfied Supporting Paragraphs

9. Develop Supporting Ideas

10. Connect the Supporting Paragraphs in the Essay

11. Write the Concluding Paragraph

12. Edit Sentence Structure

13. Edit Written Expression

\subsection{What is the required TOEFL score?}

Some universities and institutes in the country require a score of between 400-500 to pass the selection of S2 Program. S3 programs range from 450-550. The minimum required score depends on the policies and needs of the institution or university. Likewise to pass the study abroad, the required TOEFL score of at least 500, 550 or even 600 . The required score varies between universities with each other. While for promotion or promotion, the minimum score required is 450-550. In principle, the number of TOEFL scores required depends on the relevant institution.

\subsection{Classification of TOEFL Test SCORE}

In general we recognize three levels of foreign language mastery, namely Elementary, Intermediate, and Advanced. For TOEFL scores, linguists usually group these scores into the following four levels (Carson, et al., 1990):

- Elementary Level: 310 - 420

- Lower Intermediate Level: 420 - 480

- High Intermediate Level: 480 - 520

- Advanced Level: 525 - 677

\subsection{Time of the TOEFL Test Exam}

International TOEFL is usually held in April, May, October, November, and December each year. Consider what month you want to take the TOEFL test and prepare yourself to take the TOEFL test well. 
Equipment that you must carry when taking the TOEFL test include:

1. Registration form and or receipt of registration.

2. Identity card, eg KTP, SIM, or Passport.

3. $2 \mathrm{~B}$ pencil and rubber eraser.

4. Wristwatch

\subsection{Cost of TOEFL PBT Test}

The cost of taking the TOEFL PBT test generally ranges from US \$ 160 to US \$250. However, these costs are adjusted to the area of each test organizer. For Indonesia, the TOEFL PBT test charges about Rp.275,000 to Rp.300,000 for one test. 


\section{CHAPTER III}

\section{CLOSING}

\subsection{Conclusion}

TOEFL test becomes one of the requirements or benchmarks for someone who wants to enroll in college or even work in a particular company. However, many factors that cause failure when implementing toefl test is wrong that is the lack of participants to the format of the test that will be implemented and the lack of persipan both in terms of learning and time pembagin. Therefore, it is important if we need to know what the TOEFL test is, the types of TOEFL tests that will pass one of them is the TOEFL PBT test which is the first TOEFL test in which it tests four skills, namely listening, reading comprehension, grammar and structure and the last writen test. In addition, we also need to know the time provided in each section of the exam so that we can pass the entire exam just in time. Not to forget, the range of values we need to achieve should we know. This will help us pass the TOEFL test exam successfully. 


\section{REFERENCES}

https://kumpulansoaltoefl.blogspot.com/2015/02/10-faktor-penyebab-sulitmengerjakan-soal-toefl-yang-belum-anda-ketahui.html

http://www.geniustoefl.com/artikel-ilmu-kunci-toefl/artikel/pengantartoefl/institusi-toefl-dan-toefl-internasional

http://belajar-toefl-online.blogspot.co.id/2012/12/pengertian-toefl-dan-tujuantest-toefl.html

http://www.geniusedukasi.com/apa-itu-toefl/

http://www.geniustoefl.com/artikel-ilmu-kunci-toefl/artikel/pengantartoefl/strategi-dan-tips-lulus-tes-toefl-dengan-skor-tinggi

https://www.sederet.com/tutorial/tip-toefl-berapa-lama-waktu-untuk-belajartoefll

https://www.ets.org/toefl/ibt/about

http://kursustoefl.com/jenis-jenis-toefl-resmi-di-dunia-dan-dikenal-diindonesia.html 